\title{
Multiplex PCR for simultaneous identification of Ralstonia solanacearum and Xanthomonas perforans
}

\author{
S. Umesha · P. Avinash
}

Received: 22 December 2013/ Accepted: 29 April 2014/Published online: 17 May 2014

(C) The Author(s) 2014. This article is published with open access at Springerlink.com

\begin{abstract}
Ralstonia solanacearum is a causative agent of bacterial wilt in many economically important crops, and Xanthomonas perforans is the causal organism of bacterial spot, one of the most important diseases of vegetables. A multiplex PCR protocol has been developed for the simultaneous, specific and rapid identification of $R$. solanacearum and $X$. perforans in plant materials. Speciesspecific primers RS-F-759 and RS-R-760 for R. solanacearum, RST2 and RST3 for $X$. perforans were used for identification of both pathogens at primer concentrations of 1:4 by optimization of multiplex PCR at annealing temperature of about $61 \pm 1{ }^{\circ} \mathrm{C}$. With these primer sets, specific amplification of 281- and 840-bp PCR products was obtained for $R$. solanacearum and $X$. perforans, respectively. The multiplex PCR assay was validated with susceptible plants mechanically inoculated with both the pathogens; specific PCR products confirmed the presence of $R$. solanacearum and X. perforans. The multiplex PCR is valuable in identification as well as primary screening of cultivars of both pathogens. The present study is a rapid and easy method for early identification of pathogens from asymptomatic and symptomatic plant materials.
\end{abstract}

Keywords Multiplex PCR - Ralstonia solanacearum . Xanthomonas perforans - Bacterial wilt $\cdot$ Bacterial spottomato

S. Umesha $(\bowtie) \cdot$ P. Avinash

Department of Studies in Biotechnology, University of Mysore,

Manasagangotri, Mysore 570006, Karnataka, India

e-mail: umeshgroup@yahoo.co.in; pmumesh@gmail.com

\section{Introduction}

Globalization of world agriculture increases easy movement of infectious plant material across the countries, which leads to severe problems and difficulty in controlling the spread of plant pathogens, and set back in world agricultural economy by severe yield losses. Robust and inexpensive diagnostic tools are not available for easy identification and classification of many plant pathogens. The primary hurdle in developing highly specific, easily usable diagnostic tools for any pathogen has been difficult in finding unique features, whether they are cell surface antigens or DNA sequences. Therefore, there is a principal need to develop reliable, fast and specific identification methods to prevent spread of diseases caused by several phytopathogenic bacteria.

Ralstonia solanacearum causes bacterial wilt, which is one of the most important and widely spread bacterial diseases of Solanaceous crops in tropics, subtropics and warm temperate regions of the world. This disease has also been recorded in more than 200 plant species, representing over 50 families (Hayward 1994). It exhibits a strong tissue-specific tropism within the host, specifically invading and highly multiplying in the xylem vessels. In addition, it causes vascular browning, stunting, wilting and often leading to rapid death (Remenant et al. 2010). R. solanacearum is metabolically versatile and survives not only in soil but also in latently infected plants and water. The pathogen enters the plant through the roots (Xue et al. 2011). Thus, reliable methods to detect the pathogen in tubers as also in soil and soil-related habitats are required. Xanthomonas perforans is an important bacterial pathogen of vegetables particularly in tomato (Lycopersicon esculentum Mill.), causing serious economic losses worldwide (Kuflom et al. 1997). Bacterial spot disease of tomato

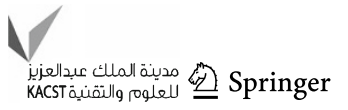


occurs in warm, moist regions throughout the world. $X$. perforans is a rod-shaped Gram-negative aerobic bacterial plant pathogen. This spot pathogen is seed-borne, persist as epiphytic populations in asymptomatic seedling and mature plants. The bacterium possesses a polar flagellum that propels them in water, which facilitates the infection of wet leaves. The primary symptoms are necrotic lesions that occur on leaves, stem and fruits. In warm and rainy weather, bacterial spot may cause severe defoliation of plants that result in reduced yield, and the diseased fruits are not suitable for fresh-market sale. Blister-like fruit lesions and stem lesions are observed in late summer. $X$. perforans can survive in dry seeds for 10 years and on plants debris redundancy up to 1 year (Isabelle et al. 2006). The impact of both the pathogens in India and world over is very high.

The most commonly used methods are not accurate for identification of disease on visual symptoms. Isolation of pathogens from plants as well as seeds by conventional techniques is often difficult. Additionally, biochemical tests, pathogenicity test and serological tests take several weeks for the final confirmation of pathogens. The sensitivity of ELISA is limited only for the detection of symptomatic plants; enrichment of target bacteria on semiselective media before ELISA improves specificity, but it is time consuming. Therefore, there is a need for rapid and specific method for routine indexing of asymptomatic and symptomatic plant materials (Lang et al. 2010).

Diagnostic tests based on the characteristics of the genomics of the bacterial pathogens can provide more reliable results, and these are not dependent on symptom expression and environmental conditions. An early DNAbased approach to distinguishing $R$. solanacearum and $X$. perforans involved amplification of $16 \mathrm{~S}$ rRNA; the approach could be useful only if supported by other sequence information such as 16S-23S rRNA internal transcribed spacers, which is able to distinguish both pathogens (Schonfeld et al. 2003; Santana et al. 2012). Species-specific PCR-based methods are commonly used in the detection and identification of pathogens with the help of species-specific primers (Adachi and Oku 2000). A multiplex PCR amplification provides reliable pathogen detection in routine testing and allows for the simultaneous amplification of more than one DNA region of interest, which is possible in a single PCR reaction mixture.

Multiplex PCR is widely applied in simultaneous, rapid, accurate detection and identification of major pathogens having different DNA or RNA targets in a single reaction. Co-amplifications of $X$. axonopodis pv. vesicatoria and Clavibacter michiganensis sub spp. michiganensis were performed in tomato plant from a single PCR tube (Ozdemir 2005). A multiplex PCR assay targeting avrBsT and xopL for the molecular identification of Xanthomonas axonopodis pv. phaseoli was validated by comparison with other molecular identification assays aimed at $X$. axonopodis pv. phaseoli, on a wide collection of reference strains. This multiplex was further validated on a blind collection of Xanthomonas isolates for which pathogenicity was assayed by stem wounding and by dipping leaves in calibrated inoculation (Boureau et al. 2013).

Identification of $R$. solanacearum and $X$. perforans is an important step, as both pathogens have been considered as potential disease threat agents all over the world. Therefore, the primary objective of the present study was to develop a multiplex PCR, specific to $R$. solanacearum and $X$. perforans for identification of pathogen in symptomatic and asymptomatic samples.

\section{Materials and methods}

\section{Bacterial isolation}

Different cultivars of tomato seed samples were collected from the public and private seed traders, Mysore, India and agriculture fields Mysore, India. Suspected plant material viz, bacterial wilt and bacterial spot symptoms along with suspected soil samples from agriculture fields was collected, brought to the laboratory and subjected to laboratory assays viz, direct plating and liquid assay methods (ISTA 2005). The suspected plant material was cut into pieces $(5 \mathrm{~mm})$; plant materials as well as seeds were surface disinfected with sodium hypochlorite $(3 \%)$ followed by repeated washing with sterile distilled water and plated on semi-selective medium [Kelman's triphenyl tetrazolium chloride (TZC; dextrose; $10 \mathrm{~g}$, tryptone; $1 \mathrm{~g}$, peptone; $10 \mathrm{~g}$, agar; $18 \mathrm{~g}$, dis $\mathrm{H}_{2} \mathrm{O} ; 1,000 \mathrm{ml}$ : triphenyl tetrazolium chloride; $0.075 \mathrm{~g}$ in $7.5 \mathrm{ml}$ )] [Tween $\mathrm{B}$ media (peptone; $10 \mathrm{~g}, \mathrm{KBr} ; 10 \mathrm{~g}, \mathrm{CaCl}_{2} ; 0.25 \mathrm{~g}$, boric acid; $0.30 \mathrm{~g}$, agar; $15 \mathrm{~g}$, Tween $80 ; 10 \mathrm{ml}$, dis $\left.\mathrm{H}_{2} \mathrm{O} ; 1,000 \mathrm{ml}\right)$ ]. Following surface-sterilization, liquid assay of the collected seeds was carried out in plant material and seed samples were macerated using sterile mortar and pestle in $10 \mathrm{ml}$ sterile distilled water. The supernatant $(1 \mathrm{ml})$ was mixed with $9 \mathrm{ml}$ of sterile distilled water to obtain a dilution of $10^{-1}$, and further serial dilutions were prepared up to $10^{-5}$. Fifty microliters of each dilution was placed on TZC and Tween B semi-selective media. In addition, the suspected soil samples from different fields were subjected to serial dilution up to $10^{-5}$ dilution, and aliquots of fifty microliters of each dilution were spread on TZC and Tween B semiselective media using Drigalski's spreaders in triplicates. Plates were incubated at $28 \pm 2{ }^{\circ} \mathrm{C}$ for $24-48 \mathrm{~h}$. The yellow colonies with hydrolytic zones were observed for $X$. perforans around the pieces of plant material and seeds, whereas typical mucoid creamy white colonies with pink 
centers were indicative for the presence of $R$. solanacearum (Hayward 1994). For positive control of $R$. solanacearum (DOBCPR 12), a pure culture used was kindly provided by Prof. Ashok Gadewar, Central Potato Research Institute, Shimla, India (Vanitha et al. 2009). These bacteria were isolated in their pure form and subjected to biochemical/physiological, hypersensitive and pathogenicity tests for confirmation of pathogens.

\section{Biochemical characterization of bacterial isolates}

Biochemical characterization of $R$. solanacearum and $X$. perforans was performed based on biochemical tests: Gram staining, KOH solubility, starch hydrolysis test (Fahy and Persley 1983), lipase activity, Kovacs' oxidase test (Kovac's 1956), gelatin hydrolysis and oxidative/fermentative metabolism of glucose.

Pathogenicity assay and hypersensitivity tests

Pathogenicity of bacterial isolates was assessed using two distinct tests. First, the virulence of $R$. solanacearum was tested with a pathogenicity assay on susceptible plants of tomato under the screen house conditions at $28 \pm 2{ }^{\circ} \mathrm{C}$. Susceptible cultivars of tomato (Cv. PKM-I) were sown in earthen pots, plants were allowed to grow for 5 weeks and used for bacterial inoculation. $R$. solanacearum, DOB-R strain was cultured in nutrient broth for $24-36 \mathrm{~h}$. The density of cell suspension was adjusted to $1 \times 10^{8} \mathrm{cfu} / \mathrm{ml}$ using spectrophotometer (Beckman Coulter, California, USA) (Lelliot and Stead 1987). This bacterial suspension was inoculated to the roots of tomato plants just below the soil surface.

Xanthomonas perforans, DOB-X strain suspension $\left(1 \times 10^{8} \mathrm{cfu} / \mathrm{ml}\right)$ was sprayed to the aerial parts of the tomato plants to completely run-off level, and plants were covered with polythene bags sprayed with water to maintain a highhumid condition. Pathogen-inoculated plants were closely monitored for the typical symptoms of both bacterial wilt and spot disease. Experiments were conducted in three replicates and repeated twice with appropriate controls.

Two milliliter of each bacterial suspension $\left(1 \times 10^{8} \mathrm{cfu} / \mathrm{ml}\right)$ was infiltrated to the leaves of 1 month old tobacco plant (Nicotiana tabacum L.) for hypersensitivity tests, with water as a controls (Carlton et al. 1998). Infiltrated tobacco plants were maintained under green house conditions with $25-30{ }^{\circ} \mathrm{C}$ in day and $15-18{ }^{\circ} \mathrm{C}$ at night and were maintained until the symptoms appeared.

Specific PCR assay and sequence analysis

Bacterial isolates from soil, seed and plant material were used for the extraction of genomic DNA from $R$. solanacearum and $X$. perforans. Bacterial DNA was isolated using bacterial genomic DNA isolation kit from BangaloreGeNei (Bangalore, India) according to the manufacturer's instruction. For identification of $R$. solanacearum, uniplex PCR was performed to amplify speI region of $R$. solanacearum using RS-F-759 and RS-R-760 primers as described by Opina et al. (1997). The specific primers RS-F-759 and RS-R-760 were custom synthesized from Chromous Biotech, Bangalore, India, RS-F (5'-GT CGCCGTCAACTCACTTTCC- $\left.3^{\prime}\right)$ and RS-R (5'-GTC GCCGTCAGCAATGCGGAATCG-3'). DNA was amplified in $25 \mu \mathrm{l}$ of reaction mixture prepared in $0.2-\mathrm{ml}$ PCR tubes by adding PCR reaction mixture containing $1 \mu \mathrm{l}$ of $100 \mathrm{mM}$ dNTPs, $2.5 \mu \mathrm{l}$ of $10 \times$ buffer, $2.0 \mu \mathrm{l}$ of $25 \mathrm{mM}$ $\mathrm{MgCl}_{2}, 1 \mathrm{U}$ of Taq DNA polymerase (Chromous Biotech, Bangalore, India), $1 \mu \mathrm{l}$ of $10-100 \mathrm{ng}$ genomic DNA and $2.0 \mu \mathrm{l}$ of each primers of $25 \mathrm{pmol}$ of $R$. solanacearum in a total volume of $25 \mu \mathrm{l}$. The PCR tubes were placed in a PCR thermocycler (Labnet, Multigene gradient, California, USA) and programmed thermal cycle as initial denaturation at $94{ }^{\circ} \mathrm{C}$ for $3 \mathrm{~min}$, annealing at $53{ }^{\circ} \mathrm{C}$ for $1 \mathrm{~min}$ and extension at $72{ }^{\circ} \mathrm{C}$ for $1 \mathrm{~min} 30 \mathrm{~s}$, followed by 30 cycles of denaturation at $94{ }^{\circ} \mathrm{C}$ for $15 \mathrm{~s}$, annealing at $60{ }^{\circ} \mathrm{C}$ for $15 \mathrm{~s}$, elongation step at $72{ }^{\circ} \mathrm{C}$ for $15 \mathrm{~s}$ and final extension at $72{ }^{\circ} \mathrm{C}$ for $5 \mathrm{~min}$.

The isolates of $X$. perforans were subjected to PCR using specific primer which was selected at $h r p B$ region of Xanthomonas campestris pv. vesicatoria strain $75-3$ as stated by Leite et al. (1994) and custom synthesized as follows (RST2-5'AGGCCCTGGAAGGTGCCCTGGA3') and (RST3-5'-ATCGCACTGCGTACCGCGCGCGA $3^{\prime}$ ). The PCR reaction mixture contained $1 \mu \mathrm{l}$ of $100 \mathrm{mM}$ dNTPs, $2.5 \mu \mathrm{l}$ of $10 \times$ buffer, $2.0 \mu \mathrm{l}$ of $25 \mathrm{mM} \mathrm{MgCl}_{2}, 1 \mathrm{U}$ of Taq polymerase (Chromous Biotech, Bangalore, India), $1 \mu \mathrm{l}$ of $10-100 \mathrm{ng}$ genomic DNA of $X$. perforans, $2.0 \mu \mathrm{l}$ of each primers $25 \mathrm{pmol}$ in a total volume of $25 \mu \mathrm{l}$. The PCR parameters were initial denaturing at $94{ }^{\circ} \mathrm{C}$ for $3 \mathrm{~min}$, followed by 30 cycles at $94{ }^{\circ} \mathrm{C}$ for $30 \mathrm{~s}, 62{ }^{\circ} \mathrm{C}$ for $30 \mathrm{~s}$, and $72{ }^{\circ} \mathrm{C}$ for $1 \mathrm{~min} 30 \mathrm{~s}$, and a final extension at $72{ }^{\circ} \mathrm{C}$ for 7 min.

Amplified PCR products were purified using QIAquick gel extraction kit (Qiagen, Hilden, Germany) following the manufacturer's instructions and sequenced commercially (Eurofins, Bangalore, India), and sequences were compared with other $R$. solanacearum and $X$. perforans sequence from data base using multiple sequence alignment software. Sequences of both pathogens were deposited in the GenBank database.

\section{Optimization of multiplex PCR}

Multiplex PCR was carried out for bacterial DNA templates isolated from mixed culture of both pathogens. A 
primer mix was used with final concentration of $100 \mathrm{pmol}$ of each primer in a ratio of $1: 4$, which was standardized among 1:1, 1:2, 1:3 and 1:4 for $R$. solanacearum and $X$. perforans, respectively. Reactions in a total volume of $25 \mu \mathrm{l}$ were performed with $1 \mathrm{U}$ of Taq DNA polymerase (Chromus Biotech, Bangalore, India). DNA was amplified in $25 \mu \mathrm{l}$ of reaction mixture containing $10 \times$ thermo pol buffer, $2 \mathrm{mM} \mathrm{MgCl}_{2}$, and $25 \mathrm{mM}$ of dATP, dCTP, dGTP and dTTP. The cycling was performed with a Master cycler Gradient (Labnet, Multigene gradient, California, USA). Gradient PCR was performed to optimize the multiplex PCR annealing temperature from 55 to $65{ }^{\circ} \mathrm{C}$. The PCR parameters were followed an initial denaturing step at $95{ }^{\circ} \mathrm{C}$ for $3 \mathrm{~min}$, followed by 30 cycles of $95^{\circ} \mathrm{C}$ for $30 \mathrm{~s}$, $61 \pm 1{ }^{\circ} \mathrm{C}$ for $1 \mathrm{~min}$ and $72{ }^{\circ} \mathrm{C}$ for $1 \mathrm{~min}$. The amplified PCR product was mixed with $2 \mu \mathrm{l}$ of loading dye and separated in $1.2 \%$ agarose gel electrophoresis by TAE buffer using $75 \mathrm{~V}$. Further, gels were documented using Geldoc 1000 System-PC (Bio-Rad, Gurgaon, India). C. michiganensis subsp. michiganensis and Pseudomonas fluorescens were used as negative controls (Table 1).

\section{Validation of multiplex PCR}

Developed multiplex PCR was validated by artificially infecting susceptible tomato plants with DOB-R and DOB$\mathrm{X}$ strains, respectively, with 20 different cultivars (five plants with four replicates) (Table 2), along with infected plants collected from agricultural fields. The seed samples were macerated using sterile mortar and pestle in $1 \mathrm{ml}$ sterile distilled water, and soil samples were serially diluted up to $10^{-3}$, and $10 \mu$ l of macerated seed sample and diluted soil samples were used as template to amplify multiplex PCR. The sensitivity of the primers was checked by diluting single-colony bacterial cultures from $10^{-1}$ up to $10^{-5}$ in sterile distilled water $(100 \mu \mathrm{l}$ in $900 \mu \mathrm{l}$ of sterile distilled water) without isolating DNA from the bacterial cultures in this multiplex PCR, and gel was documented using Geldoc 1000 System-PC (Bio-Rad, Gurgaon, India).

\section{Results and discussion}

The bacterial wilt-causing pathogen $R$. solanacearum and bacterial spot-causing pathogen $X$. perforans in tomato plants were isolated and characterized. Plant material, seed samples and soil samples were subjected to laboratory assays such as direct plating and liquid assay. The samples showed the presence of both the pathogens. Isolates of $R$. solanacearum from soil, plant material and seeds were cultured using semi-selective media, and typical mucoid creamy white colonies with pink centers were observed. $X$. perforans colonies on Tween B media exhibited typical
Table 1 Mixed culture, isolation of $R$. solanacearum and $X$. perforans from different sources and their reaction to multiplex PCR

\begin{tabular}{|c|c|c|c|c|}
\hline \multirow[t]{2}{*}{ Source } & \multirow{2}{*}{$\begin{array}{l}\text { Isolates of } R \text {. } \\
\text { solanacearum }\end{array}$} & \multirow{2}{*}{$\begin{array}{l}\text { Isolates of } X \text {. } \\
\text { perforans }\end{array}$} & \multicolumn{2}{|l|}{ Multiplex PCR } \\
\hline & & & $\begin{array}{l}R . \\
\text { solanacearum }\end{array}$ & $\begin{array}{l}X . \\
\text { perforans }\end{array}$ \\
\hline Soil & RS 1 & XP 1 & + & + \\
\hline Soil & RS 2 & XP 2 & + & + \\
\hline Soil & RS 3 & XP 3 & + & + \\
\hline Soil & RS 4 & XP 4 & + & + \\
\hline Soil & RS 5 & XP 5 & + & + \\
\hline $\begin{array}{l}\text { Plant } \\
\text { material }\end{array}$ & RS 6 & XP 6 & + & + \\
\hline $\begin{array}{l}\text { Plant } \\
\text { material }\end{array}$ & RS 7 & XP 7 & + & + \\
\hline $\begin{array}{l}\text { Plant } \\
\text { material }\end{array}$ & RS 8 & XP 8 & + & + \\
\hline $\begin{array}{l}\text { Plant } \\
\text { material }\end{array}$ & RS 9 & XP 9 & + & + \\
\hline $\begin{array}{l}\text { Plant } \\
\text { material }\end{array}$ & RS 10 & XP 10 & + & + \\
\hline Seed & RS 11 & XP 11 & + & + \\
\hline Seed & RS 12 & XP 12 & + & + \\
\hline Seed & RS 13 & XP 13 & + & + \\
\hline Seed & RS 14 & XP 14 & + & + \\
\hline Seed & RS 15 & XP 15 & + & + \\
\hline Seed & RS 16 & XP 16 & + & + \\
\hline Seed & RS 17 & XP 17 & + & + \\
\hline Seed & RS 18 & XP 18 & + & + \\
\hline Seed & RS 19 & XP 19 & + & + \\
\hline Seed & RS 20 & XP 20 & + & + \\
\hline Seed & $\mathrm{Cmm}$ & $\mathrm{Cmm}$ & - & - \\
\hline Seed & PS & PS & - & - \\
\hline
\end{tabular}

RS 1-RS 5. Bacterial isolates isolated from serial dilution method, RS 6-RS 10. Bacterial isolates isolated from direct plating method of plant materials (stem), RS 11-Rs 15. Bacterial isolates isolated from direct plating method of seeds, RS 16-RS 20. Bacterial isolates isolated from liquid assay method for seeds

XP 1-XP 5. Bacterial isolates isolated from serial dilution method, XP 6-XP 10. Bacterial isolates isolated from direct plating method of plant materials (leaves), XP 11-XP 15. Bacterial isolates isolated from direct plating method of seeds, XP16-XP 20. Bacterial isolates isolated from liquid assay method for seeds

Cmm. Clavibacter michiganensis subsp. michiganensis and PS. Pseudomonas fluorescens bacterial isolate isolated from direct plating method of seed and soil, respectively

morphological characteristics such as yellow colonies with hydrolytic zones. Further, different isolates of $R$. solanacearum and $X$. perforans were subjected to biochemical/ physiological assays along with hypersensitivity and pathogenicity tests. Phytobacterial pathogens, C. michiganensis subsp. michiganensis and P. fluorescens were also isolated from the collected seed and soil samples, respectively (Table 1). 
Table 2 Mixed infection of pathogens in susceptible plants compared by pathogenicity test and multiplex PCR
"+" indicates the positive reaction; "-" indicates negative reaction of phytopathogenic bacteria

\begin{tabular}{|c|c|c|c|c|c|}
\hline \multirow[t]{2}{*}{ Bacterial isolates } & \multirow[t]{2}{*}{ Tomato cultivars } & \multicolumn{2}{|c|}{ Response to pathogenicity test } & \multicolumn{2}{|c|}{ Response to multiplex PCR } \\
\hline & & $R$. solanacearum & $X$. perforans & R. solanacearum & $X$. perforans \\
\hline 1 & Ark-Abha & + & + & + & + \\
\hline 2 & Ashwini-FI & + & + & + & + \\
\hline 3 & Arunodaya & + & + & + & + \\
\hline 4 & Indosem & + & + & + & + \\
\hline 5 & Indam & + & + & + & + \\
\hline 6 & Madanapalli & + & + & + & + \\
\hline 7 & Malini & + & + & + & + \\
\hline 8 & MPH-I & + & + & + & + \\
\hline 9 & OK Seed & + & + & + & + \\
\hline 10 & PKM-I & + & + & + & + \\
\hline 11 & Sarapana & + & + & + & + \\
\hline 12 & HCl-IV & + & - & + & - \\
\hline 13 & Local-I & + & - & + & + \\
\hline 14 & PHS & + & - & + & + \\
\hline 15 & Ashoka & - & - & + & + \\
\hline 16 & Alrounder & - & - & + & + \\
\hline 17 & Rasi & - & + & - & - \\
\hline 18 & Quality & - & + & - & - \\
\hline 19 & Vignesh & - & - & + & - \\
\hline 20 & Mrytunjaya & - & - & - & + \\
\hline
\end{tabular}

$R$. solanacearum and $X$. perforans were subjected to biochemical characterization, both pathogens stained pink red for Gram's reaction and thin viscid mucoid strand for $\mathrm{KOH}$ solubility indicating Gram's negative in nature. $X$. perforans liquefied gelatin media when compared control and show a clear zone of hydrolysis around the bacterial colonies when flooded with Lugol's iodine on starch hydrolysis' test. Lypolytic activity was confirmed positive by the presence of a white precipitate around the colonies of $X$. perforans in Tween 80 agar plates. $R$. solanacearum designate negative for gelatin hydrolysis, starch hydrolysis test as well as lipase activity tests. Kovac's oxidase tests show a positive result by immediate change in the color to blue in $R$. solanacearum, but it was negative in $X$. perforans. $R$. solanacearum changed the color of media from green to yellow, indicating positive results for oxidation test, whereas in the fermentation test, both these pathogens did not show any reaction.

Susceptible tomato cultivars when inoculated with $R$. solanacearum isolated from the soil, seed and plant material showed bacterial wilt symptoms such as vascular browning, stunting, wilting and often with rapid death of tomato plants. Control plants did not show any disease symptoms. $X$. perforans isolates showed bacterial spot symptoms, whereas control plants with nutrient broth did not show any symptoms. Yellowing of leaf followed by necrosis was evident in tobacco plants within $48 \mathrm{~h}$ of infiltration with both bacterial isolates, whereas control leaves did not show any change in leaf morphology. Biochemical/physiological tests, hypersensitivity and pathogenicity tests were used in the identification and confirmation of the isolated pathogens as $R$. solanacearum and $X$. perforans, but these tests are time consuming. Our main objective was to develop a reliable multiplex PCR assay for the identification of these pathogens. This new PCR assay combines two different tests first, high specificity in the identification of the pathogens. The results of present study are in confirmation with the studies reported, earlier (Chandrashekar et al. 2012; Avinash and Umesha 2014).

Polymerase chain reaction technique has found wide application in detecting plant pathogenic bacteria (Adachi and Oku 2000). Targeting 16S-23S spacer region is not specific, but it is also fast and easy. A multiplex "Taq man" PCR method was described by Weller et al. (2000) for specific identification of $R$. solanacearum in potato tubers extract, the developed multiplex PCR described here is a simple, with lower cost and an alternative to the "Taq man" method. A multiplex PCR method for detection and differentiation of $R$. solanacearum strains compared with $16 \mathrm{~S}-23 \mathrm{~S}$ rRNA primers with the use of sequence analysis which differentiate $R$. solanacearum subclasses which is also cost effective for large-scale screening. The $16 \mathrm{~S}-23 \mathrm{~S}$ spacer region has large copy number (more than 10,000 per cell) and high degree of sequence conservation, which are the drawbacks of 16S-23S primers Pastrik et al. (2002). 
Fig. 1 Optimized multiplex PCR for both $R$. solanacearum and $X$. Perforans. Lanes 1 and 2 amplification of $R$. solanacearum annealing temperature at 57 and $61{ }^{\circ} \mathrm{C}$. Lanes 3 and 4 amplification of $X$. perforans annealing temperature at 58 and $64{ }^{\circ} \mathrm{C}$. Lanes 5-7 multiplex PCR of $R$. solanacearum and $X$. perforans $61 \pm 1{ }^{\circ} \mathrm{C} .50$ bp $(M)$ Gene ladder

Fig. 2 Multiplex PCR for both $R$. solanacearum and $X$. perforans. Lanes 1-20 mixed culture of $R$. solanacearum and $X$. Perforans amplified at 281 and 840 bp. (N) Negative control Clavibacter michiganensis subsp. michiganensis and Pseudomonas fluorescens. 100-bp DNA marker $(M)$
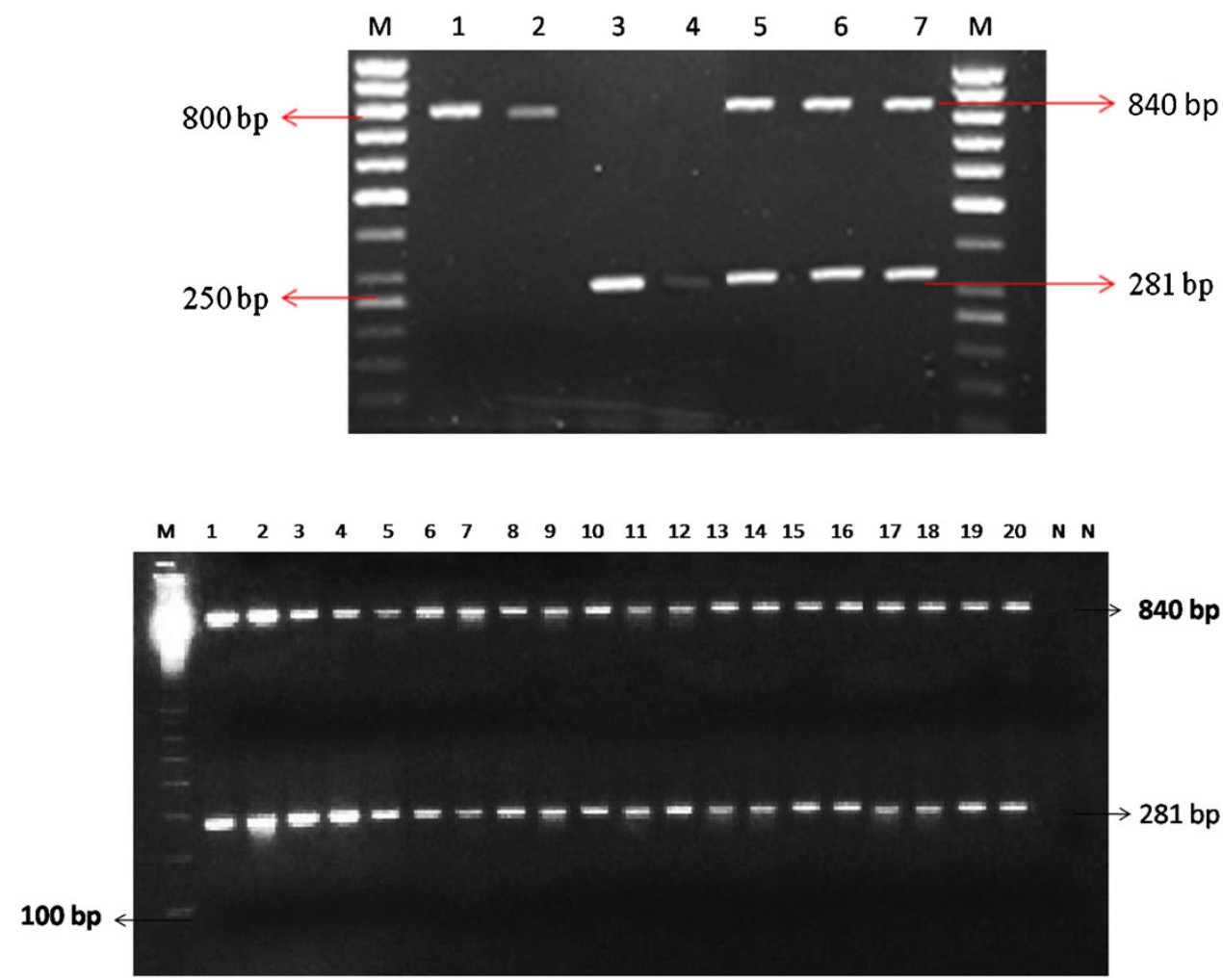

$R$. solanacearum subjected to specific PCR assay using specific primers viz, RS-F-759 and RS-R-760 showed a specific amplification at $281 \mathrm{bp}$, confirmed as $R$. solanacearum. Primers RST2 and RST3 showed an amplification of 840-bp amplicon in genome confirmed as $X$. perforans. To confirm primer specificity, homology test for primers was carried out using BLAST search considering query coverage and percentage identity for both pathogens, in which RS-F-759 and RS-R-760 primers showed 100, 95 and $75 \%$ homology to $R$. solanacearum, R. syzygii and Oryza minuta, respectively, whereas same primers did not show homology with Xanthomonas. The hrp B primers did not show $100 \%$ identity with $X$. oryzae pv. oryzae, $X$. oryzae pv. oryzicola and X. fuscans subsp. fuscans, whereas hrp $B$ primers did not show homology with $R$. solanacearum. Identities of pathogens were further confirmed by sequencing of amplified products of $R$. solanacearum and $X$. perforans, and sequences were deposited in the GenBank database (accession numbers JX628912 and JX628913). To examine further the extant of sequence variation present in $R$. solanacearum and $X$. perforans, nucleotide sequence of other strains of both pathogens from GenBank database was compared. The result revealed that $100 \%$ homology with other $R$. solanacearum strains, whereas $X$. perforans sequence showed partial similarity with $X$. oryzae pv. oryzae, but it showed a non-specific amplification when cross-tested with primers RST2 and RST3.
A single gradient multiplex PCR was used to detect $R$. solanacearum and $X$. perforans by determining the range of annealing temperature. The gradient multiplex PCR was carried out using annealing temperature from 55 to $65{ }^{\circ} \mathrm{C}$, PCR amplified an amplicon of $281 \mathrm{bp}$ for $R$. solanacearum in gradient PCR, whereas the intensity of bands was decreased continuously at increasing the annealing temperature from 57 to $61{ }^{\circ} \mathrm{C}$ and amplifications were not observed above $61^{\circ} \mathrm{C}$ for $R$. solanacearum. X. perforans showed decreased intensity of the band for annealing temperature range from 57 to $61{ }^{\circ} \mathrm{C}$, whereas amplifications were observed at 840 -bp amplicon at $61{ }^{\circ} \mathrm{C}$, thereby standardizing the concentration of DNA and concentration of primers efficacy with respect to $X$. perforans. In primer concentration of $1: 4, R$. solanacearum and X. perforans, respectively, showed optimum amplifications at the annealing temperature $61 \pm 1{ }^{\circ} \mathrm{C}$ (Fig. 1). C. michiganensis subsp. michiganensis and P. fluorescens did not show any amplification in multiplex PCR. All isolates collected from field conditions viz, seed samples, plant material along with soil samples (Table 1) amplified in a multiplex PCR simultaneously which confirms both pathogens as $R$. solanacearum and $X$. perforans (Fig. 2). Earlier, a multiplex PCR assay was developed for simultaneous detection of C. michiganensis subsp. michiganensis, Pseudomonas syringae pv. tomato and $X$. axonopodis pv. vesicatoria (Ozdemir 2009). The present multiplex PCR technique developed could be a very useful approach for early 


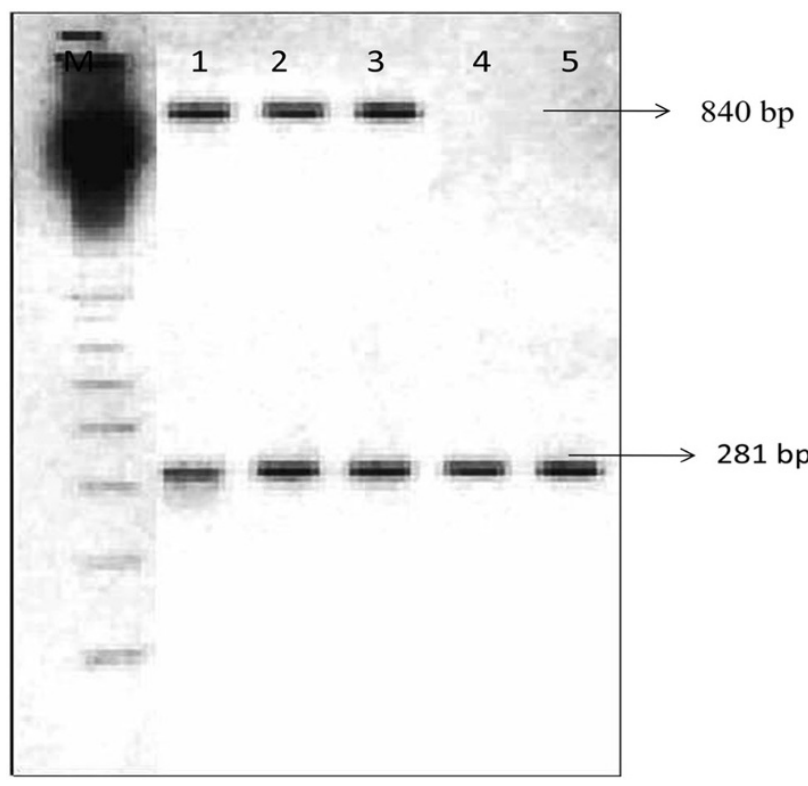

Fig. 3 Multiplex PCR amplification of $R$. solanacearum and $X$. perforans from different soil samples. Amplification at $840 \mathrm{bp}$ indicates $X$. perforans, and amplification at $281 \mathrm{bp}$ indicates $R$. solanacearum 100-bp DNA $(M)$

identification of $R$. solanacearum and X. perforans in the current agriculture. On the basis of $23 \mathrm{~S}$ rRNA gene sequences, one universal forward and four taxon-specific reverse primers were designed for multiplex PCR to aid in identification and differentiation of Agrobacterium rubi, A. vitis and $A$. biovars 1 and 2 (Puławska et al. 2006). The multiplex PCR can be a better tool for rapid classification of similar species and taxa of phytopathogenic bacteria which can be used to identify different biovars among $R$. solanacearum and $X$. perforans. The developed multiplex PCR is more efficient than a single PCR reaction in saving time and reduces reaction cost by simultaneous amplification of pathogens.

Twenty different tomato cultivars (five plants in four replicates) were artificially inoculated with the isolates of $R$. solanacearum and $X$. perforans to validate multiplex PCR (Table 2). Leaves were collected from inoculated plants after 8-10 days, and pathogens were isolated by plating the leaves on nutrient agar media. In addition, multiplex PCR performed to identify $R$. solanacearum and $X$. perforans from single-colony PCR to increase sensitivity of amplification. Both the pathogens amplified up to $10^{-3}$ dilution, indicating that the developed method is useful for identification of both the phytobacterial pathogens without DNA isolation (Fig. 2), correspondingly seed and soil samples which also showed amplification in $10^{-2}$ dilution which validate the developed multiplex is extremely valuable in early diagnosis of pathogen from seed, soil (Fig. 3) as well as plant materials. The number of contaminations within a system may be low, thereby making it difficult to detect infested soil, plant material and seeds. To tackle these issues, a multiplex PCR technique was developed in the present study is of great value to distinguish $R$. solanacearum and X. perforans. The multiplex PCR was found to be a better technique as it could detect more positiveinfected seed samples when compared to the conventional method. The pathogenicity test conducted in susceptible plants of tomato isolates 12-16 exhibited negative results, whereas it showed positive results in multiplex PCR. Interestingly, the isolate 17 (Rasi) gave positive for pathogenicity, but negative in multiplex PCR which overcomes the false positive results (Table 2). Multiplex PCR protocols have been developed to detect several pathogens or genetically heterogeneous strains of a single pathovar simultaneously. Even detection of one bacterium and four viruses was reported by multiplex PCR in olive plants (Bertolini et al. 2003). The early diagnosis of bacterial wilt and spot diseases in this crop is very essential in current scenario to develop suitable management strategies which lead to improvement in the yield of agricultural products.

\section{Conclusion}

It can be concluded that the multiplex PCR technique described in the present study is a reliable, sensitive and cost effective procedure for identifying $R$. solanacearum and $X$. perforans. The present technique developed is useful for international sanitary surveillance of planting material exchanges. Additionally, this molecular tool can be useful to determine the relationship between soil/seed contamination and disease incidence of $R$. solanacearum and $X$. perforans in tomato. Furthermore, this method can assess the relative importance of different stages of dissemination of these pathogens.

Acknowledgments This work was supported by the grants from major research project on "Development of PCR-SSCP technique for specific diagnosis of bacterial spot and bacterial wilt pathogens in tomato" awarded by University Grants Commission, Government of India, New Delhi, India, under grant 11th Plan [36-281/2008 (SR)].

Conflict of interest There is no conflict of interest.

Open Access This article is distributed under the terms of the Creative Commons Attribution License which permits any use, distribution, and reproduction in any medium, provided the original author(s) and the source are credited.

\section{References}

Adachi N, Oku T (2000) PCR-mediated detection of Xanthomonas oryzae pv. oryzae by amplification of the $16 \mathrm{~S}-23 \mathrm{~S}$ rDNA spacer region sequence. J Gen Plant Pathol 66:303-309 
Avinash P, Umesha S (2014) Identification and genetic diversity of bacterial wilt pathogen in brinjal. Arch Phytopathol Plant Prot 47(4):398-406

Bertolini E, Olmos A, Lopez MM, Cambra M (2003) Multiplex nested reverse-transcription polymerase chain reaction in a single tube for sensitive detection of four RNA viruses and Pseudomonas savastanoi pv. savastanoi in olive trees. Phytopathology 93:286-292

Boureau T, Kerkoud M, Chhel F, Hunault G, Darrasse A, Brin C, Durand K, Hajri A, Poussier S, Manceau C, Lardeux F, Saubion F, Jacques MA (2013) A multiplex-PCR assay for identification of the quarantine plant pathogen Xanthomonas axonopodis pv. phaseoli. J Microbiol Methods 92:42-50

Carlton WM, Braun EJ, Gleason ML (1998) Ingress of Clavibacter michiganensis ssp. michiganensis into tomato leaves through hydathodes. Phytopathology 88:525-529

Chandrashekar S, Umesha S, Chandan S (2012) Molecular detection of phytopathogenic bacteria using polymerase chain reaction signal-strand confirmation polymorphism. Acta Biochim Biophys Sin 44:217-223

Fahy PC, Persley GJ (1983) Plant bacterial diseases, a diagnostic guide. Academic Press, USA 393

Hayward AC (1994) Characteristics of Pseudomonas solanacearum. J Appl Bacteriol 27:265-277

Isabelle RS, Philippe L, Lionel G, Emmanuel J, Olivier P (2006) Specific detection of Xanthomonas axonopodis pv. dieffenbachiae in Anthurium (Anthurium andreanum) tissues by nested PCR. Appl Environ Microbiol 72:1072-1078

ISTA (2005) International rules for seed testing. In: Draper SR ed. Rules. Switzerland: International Seed Testing Association, Zurich, 1: 520

Kovac's N (1956) Identification of Pseudomonas pyocyanea by the oxidase reaction. Nature 178:703

Kuflom M, Kuflu DA, Cuppels (1997) Development of a diagnostic DNA Probe for Xanthomonads causing bacterial spot of peppers and tomatoes. Appl Environ Microbiol 63:4462-4470

Lang JM, Hamilton JP, Diaz MG, Van SMA, Burgos MRG, Vera CM (2010) Genomics-based diagnostic marker development for Xanthomonas oryzae pv. oryzae and X. oryzae pv. oryzicola. Plant Dis 94:311-319

Leite RP, Minsavage GV, Bonas U, Stall RE (1994) Detection and identification of phytopathogenic Xanthomonas strains by amplification of DNA sequence related to the $h r p$ genes of Xanthomonas campestris pv. vesicatoria. Appl Environ Microbiol 60:1069-1077

Lelliot RA, DE Stead (1987) Methods for the diagnosis of bacterial diseases of plants. In: Preece TF (ed) Methods in plant pathology. Blackwell Scientific Publications, New Jersey, p 216
Opina N, Tavner F, Hollway G, Wang JF, Li TH, Maghirang R, Fegan M, Hayward AC, Krishnapillai V, Hong WF, Holloway BW, Timmis J (1997) A novel method for development of species and strain-specific DNA probes and PCR primers for identifying Burkholderia solanacearum (formerly Pseudomonas solanacearum). Asia Pac J Mol Biol Biotechnol 5:19-30

Ozdemir Z (2005) Development of a multiplex PCR assay for concurrent detection of clavibacter michiganensis subsp. michiganensis and xanthomonas axonopodis pv. vesicatoria. Plant Pathol J 4:133-137

Ozdemir Z (2009) Development of a multiplex PCR assay for the simultaneous detection of clavibacter michiganensis subsp. michiganensis, pseudomonas syringae pv. tomato and Xanthomonas axonopodis pv. vesicatoria using pure cultures. J Plant Pathol 91:495-497

Pastrik KH, Elphinstone GH, Pukall R (2002) Sequence analysis and detection of Ralstonia solanacearum by multiplex PCR amplification of $16 \mathrm{~S}-23 \mathrm{~S}$ ribosomal intergenic spacer region with internal positive control. Eur J Plant Pathol 108:831-842

Puławska J, Willems A, Sobiczewski P (2006) Rapid and specific identification of four Agrobacterium species and biovars using multiplex PCR. Syst Appl Microbiol 29:470-479

Remenant B, Goutaland BC, Guidot A, Cellier G, Wicker E, Allen C, Fegan M, Pruvost O, Elbaz M, Calteau A, Salvignol G, Mornico D, Mangenot S, Barbe V, Médigue C, Prior P (2010) Genomes of three tomato pathogens within the Ralstonia solanacearum species complex reveal significant evolutionary divergence. BMC Genom 11:379

Santana GB, Lopes AC, Elba A, Cristine CB, Allen C, Quirino BF (2012) Diversity of Brazilian biovar 2 strains of Ralstonia solanacearum. J Gen Plant Pathol 78:190-200

Schonfeld J, Heuer H, van-Elsas JD, Smalla K (2003) Specific detection of Ralstonia solanacearum in soil on the basis of PCR amplification of fliC fragments. Appl Environ Microbiol 69:7248-7256

Vanitha SC, Niranjana SR, Umesha S (2009) Role of phenylalanine ammonia lyase and polyphenol oxidase in host resistance to bacterial wilt of tomato. J Phytopathol 157:552-557

Weller SA, Elphinstone JG, Smith NC, Boonham N, Stead DE (2000) Detection of Ralstonia solanacearum strains with a quantitative multiplex, real-time, fluorogenic PCR (TaqMan) assay. Appl Environ Microbiol 66:2853-2858

Xue QY, Ni YY, Wei Y, Holger H, Philippe P, Hua GJ, Kornelia S (2011) Genetic diversity of Ralstonia solanacearum strains from China assessed by PCR-based fingerprints to unravel host plant and site-dependent distribution patterns. FEMS Microbiol Ecol 75:507-519 